\title{
Perancangan Sistem Microgrid Untuk Mempercepat Akses Terhadap Energi Listrik (Energy Access) Pada Kawasan Wisata Setu Rawalumbu Kota Bekasi
}

\author{
Charles O.P. Marpaung ${ }^{1}$, Uras Siahaan ${ }^{2}$, Margareta M. Sudarwani ${ }^{3}$ \\ 1,2,3 Universitas Kristen Indonesia, Jakarta, Indonesia \\ E-mail: cop.marpaung@gmail.com; urassiahaan@yahoo.com; \\ margareta.sudarwani@uki.ac.id
}

\begin{abstract}
Abstrak
Setu Rawalumbu, Kecamatan Rawalumbu, Kota Bekasi, Propinsi Jawa Barat, Indonesia adalah satu dari ribuan setu yang ada di Indonesia, yang masih belum dimanfaatkan secara optimal, Permen PUPR No. 9 Tahun 2015 Tentang Penggunaan Sumber Daya Air pada pasal 43 ayat (2), dan Permen PUPR No. 28 Tahun 2015 Tentang Garis Sempadan Sungai dan Garis Sempadan Danau pada pasal 23. Ini bisa dilihat dari munculnya banyak perumahan di daerah tersebut termasuk fasilitas umum dan fasilitas sosial, dan menjadi tempat pembuangan sampah yang berasal dari daerah sekitar. Setu ini juga dicanangkan sebagai Daerah Kawasan Wisata yang fokusnya pada eko-wisata (eco-tourism), yang akan memberikan manfaat ekonomi kepada masyarakat setempat dan mendukung upaya pelestarian lingkungan alam dan budaya. Sebagai Daerah Kawasan Wisata, energi listrik yang berkelanjutan di Setu ini perlu dioptimalkan sesuai dengan kriteria goal ke 7 dari Sustainable Development Goals (SDGs), dengan membangun microgrid energi terbarukan dengan back-up generator diesel dan memanfaatkan potensi sumberdaya matahari. Energi listrik yang dibangkit dari sinar matahari melalui solar PV adalah energi yang bersih atau hijau (clean energy atau green energy). Sistem ini lebih andal, murah dan berdampak lingkungan rendah. Dengan cara ini, Daerah Kawasan Wisata Setu Rawalumbu dapat menjadi daerah eko-wisata (eco-tourism).
\end{abstract}

Kata Kunci: Setu; Rawalumbu; Energi.

\begin{abstract}
Setu Rawalumbu, Rawalumbu Sub-District, Bekasi City, West Java Province, Indonesia is one of thousands of Ponds in Indonesia, which is still not optimally utilized, PUPR Regulation No. 9 of 2015 concerning Use of Water Resources in article 43 paragraph (2), and PUPR Minister Regulation No. 28 of 2015 concerning River Borderline and Lake Borderline in article 23. This can be seen from the emergence of a lot of housing in the area including public and social facilities, and becoming a landfill that comes from the surrounding area. This pond is also declared as a Regional Tourism Area which focuses on eco-tourism, which will provide economic benefits to the local community and support efforts to preserve the natural and cultural environment. As a Tourism Area Region, sustainable electricity in the pond needs to be optimized according to the 7th goal criteria of Sustainable Development Goals (SDGs), by building renewable energy microgrids with back-up diesel generators and utilizing the potential of solar resources. Electrical energy that is generated from sunlight through solar PV is clean or green energy. This system is more reliable, inexpensive and has a low environmental impact. In this way, the Setu Rawalumbu Regional Tourism Area can become an eco-tourism area.
\end{abstract}

Keywords: Setu; Rawalumbu; Renewable Energy. 
Volume 2, Nomor 1, Tahun 2020 Hal 352 - 378

\section{PENDAHULUAN}

Setu atau situ merupakan sebutan istilah lokal yang merupakan cekungan pada permukaan bumi yang berisi air atau wadah genangan air di atas permukaan tanah yang terbentuk secara alamiah atau buatan. Sumber air setu berasal dari mata air, air hujan, dan/atau limpasan air permukaan. Berdasarkan Permen PUPR No. 9 Tahun 2015 Tentang Penggunaan Sumber Daya Air pada pasal 43 ayat (2), dan Permen PUPR No. 28 Tahun 2015 Tentang Garis Sempadan Sungai dan Garis Sempadan Danau pada pasal 23, setu dan sempadan setu dapat difungsikan dan dimanfaatkan untuk berbagai tujuan. Setu sangat penting keberadaannya karena memiliki nilai ekologi, ekonomi, edukatif, serta estetika sekaligus. Secara ekologis, setu merupakan reservoir alami yang dapat dimanfaatkan sebagai konservasi lahan, habitat bagi berbagai jenis tumbuhan dan hewan, daerah penampungan dan resapan air, sumber air bagi kehidupan atau pemasok cadangan air tanah, mengurangi tingkat resiko bencana kekeringan di musim kemarau maupun banjir di musim penghujan, menghadapi perubahan pola musim, pengatur iklim mikro, pendinginan suhu udara kota, habitat satwa liar, dan sebagainya. Secara ekonomis, setu dapat dijadikan sebagai lahan perikanan atau media budaya ikan, penghasil berbagai jenis sumberdaya alam bernilai ekonomis, penghasil energi, sarana wisata dan olah raga air (perahu dayung, kano, memancing). Setu juga mempunyai unsur edukatif sebagai tempat melakukan penelitian dan pengembangan ilmu pengetahuan. Pada setu juga kita dapat belajar ekosistem, khususnya ekosistem setu, yaitu sebutan untuk kesatuan antara alam beserta lingkungan dengan makhluk hidup ataupun organisme yang hidup di dalamnya, dimana ekosistem akan membentuk suatu hubungan timbal balik untuk saling memberikan pengaruh diantara keduanya. Perlu dicatat bahwa ekosistem selalu berbeda-beda berdasarkan tempatnya, misalnya saja ekosistem pantai, ekosistem sungai, ekosistem laut, ekosistem danau, ekosistem setu, dan sebagainya. Secara estetika, setu dapat dipergunakan sebagai penambahan keindahan kota. Sering kali setu tersebut dimanfaatkan secara terpadu, yaitu antara wisata alam, budaya dan pendidikan dengan karakteristik yang spesifik, yaitu kepeduliannya pada kegiatan konservasi alam dan kepentingan ekonomi, serta keberlangsungan budaya masyarakat setempat. Kegiatan tersebut disebut dengan eko-wisata (ecotourism). Dengan eko-wisata, maka berbagai kepentingan dapat dipadukan dengan baik untuk meningkatkan partisipasi masyarakat dalam pengelolaan, sehingga memberikan manfaat ekonomi kepada masyarakat setempat sekaligus mendukung upaya pelestarian lingkungan alam dan budaya. Oleh karena manfaatnya yang begitu besar, maka perlu dilakukan revitalisasi terhadap setu ataupun reservoir-reservoir yang terbentuk secara alami ataupun buatan. 
Volume 2, Nomor 1, Tahun 2020 Hal 352 - 378

Setu pada awalnya adalah daerah yang difungsikan untuk memelihara keseimbangan ekosistem, dengan mengutamakan nilai ekologis diatas kepentingan yang lain. Oleh karena itu, di daerah setu umumnya tidak ada aktifitas kehidupan yang dilakukan oleh manusia. Kalaupun akhirnya di daerah setu ada kehidupan dimana rumah-rumah penduduk sudah banyak yang muncul (contohnya di Kawasan Wisata Setu Rawalembu), serta muncul berbagai aktifitas untuk menunjang kehidupan mereka, itu disebabkan karena peruntukan setu tidak dipergunakan dengan sesuai tata ruang yang benar. Oleh karena setu bukan merupakan tempat untuk ditinggali, maka akses terhadap energi lisrik di setu umumnya sangat rendah. Perlu diingat bahwa akses terhadap energi listrik (energy access), tidak hanya masalah sambungan jaringan listrik dari pengelola (yang mengusahakan energi listrik) ke konsumen, tetapi juga dengan melihat faktorfaktor lain, misalnya legalitas, keamanan, kualitas daya, kuantitas daya, lingkungan, dan lain-lain, sesuai dengan point 7 dari Sustainable Development Goals (DPGs). Listrik sangat penting karena listrik merupakan driver dari semua kegiatan yang ada di daerah setu. Jika setu akan dimanfaatkan seperti yang dijelaskan diatas, maka listrik harus dapat diakses di daerah tersebut.

\section{Perumusan Masalah}

Energi merupakan salah satu driver yang sangat penting dalam menjalankan segala aktifitas yang ada di Kawasan Wisata
Setu Rawalumbu. Jika sistem berjalan dengan baik, maka aktifitas di daerah tersebut akan mempunyai multiplier effects, baik backward effects, maupun forward effects, yang semuanya itu akan berdampak terhadap pertumbuhan ekonomi di daerah tersebut. Jika energi yang dibutuhkan tidak mencukupi, maka semua aktifitas yang sudah direncanakan di daerah tersebut akan tidak berjalan dengan lancar. Oleh karena itu, dibutuhkan akses terhadap energi listrik di Kawasan Wisata Setu Rawalumbu. Di Kawasan Wisata Setu Rawalumbu sendiri sebenarnya sudah masuk jaringan listrik dari PT. PLN. Namun jaringan listrik yang mensuplai listrik ke konsumen-konsumen di daerah tersebut hanya sebatas konektifitas saja (sambungan kabel listrik dari PT. PLN ke konsumen), dan tidak memenuhi persyaratanpersyaratan energy access seperti yang diminta oleh Sustainable Development Goals (SDGs), yaitu kemampuan untuk mensuplai energi yang memadai, tersedia saat dibutuhkan, andal, berkualitas baik, terjangkau, legal, nyaman, sehat, dan aman untuk semua pengguna energi di seluruh rumah tangga, perusahaan produktif, dan lembaga masyarakat. Oleh karena itu yang menjadi pertanyaan dan perlu dipikirkan adalah bagaimana agar energy access di Kawasan Wisata Setu Rawalumbu dapat ditingkatkan sesuai dengan kriteria Sustainable Development Goals (SDGs), sehingga Kawasan Wisata Setu Rawalumbu dapat berfungsi seperti yang diinginkan, baik 
Volume 2, Nomor 1, Tahun 2020 Hal 352 - 378

untuk jangka pendek, menengah, dan panjang.

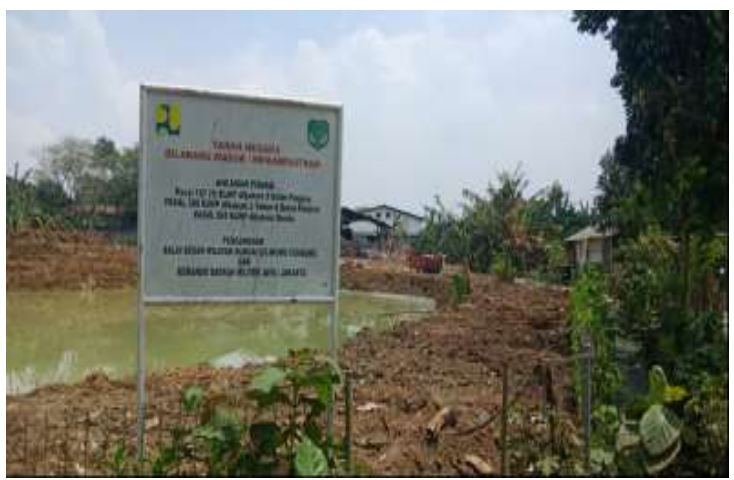

Gambar 1. Kondisi Awal Setu Rawalumbu

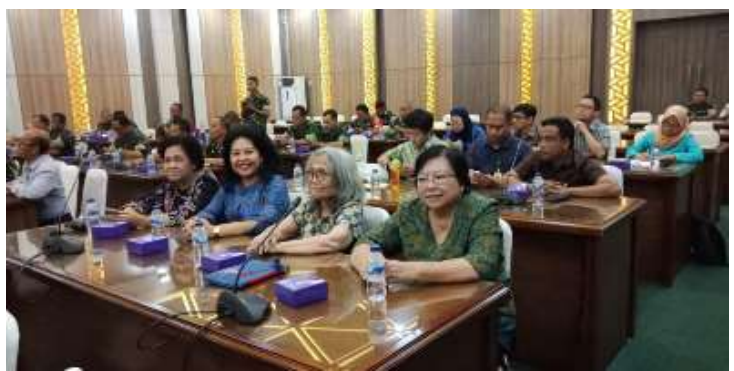

Gambar 2. Rapat Koordinasi di Kodam Jaya

\section{METODOLOGI PERANCANGAN SISTEM MICROGRID}

Perancangan microgrid yang akan dipergunakan di Kawasan Wisata Setu Rawalumbu membutuhkan beberapa langkah pelaksanaan mulai dari kunjungan lapangan sampai mendapatkan sistem microgrid yang optimal. Gambar 2.1 menunjukkan metodologi perancangan sistem microgrid untuk Kawasan
Wisata Setu Rawalumbu. Metodologi perancangan terdiri atas beberapa langkah dan prosedur dan dikombinasikan dengan analisa teknik dan analisa ekonomi yang dilakukan dengan mempergunakan HOMER Pro. Langkah-langkah perancangan tersebut secara garis besar dimulai dari kunjungan lapangan utuk mencari permasalahan yang terjadi di lapangan, dalam hal ini di Kawasan Wisata Setu Rawalumbu. Melalui kunjungan lapangan dan studi pustaka khususnya yang berhubungan dengan penggunaan energi, khususnya energi listrik, diperoleh informasi sumber-sumber energi terbarukan serta potensinya. Langkah selanjutnya mencari solusi untuk memecahkan permasalahan yang ada dengan mempertimbangkan berbagai kendala yang ada seperti faktor-faktor ekonomi, jenis teknologi dan komponen yang akan dipergunakan, serta validasi biaya dan parameter-parameter yang dipergunakan untuk melakukan analisa sensitivitas. Dari sini diperoleh rancangan microgrid energi terbarukan yang paling optimal untuk dioperasikan di Daerah Kawasan Wisata Setu Rawalumbu. 


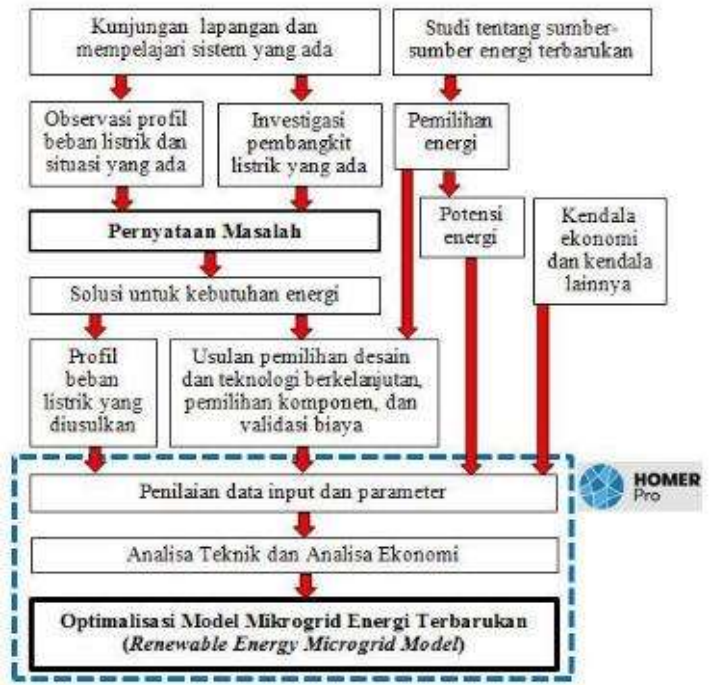

Gambar 3. Metodologi Perancangan Sistem Microgrid Pada Kawasan Wisata Setu Rawalumbu

\section{HASIL DAN PEMBAHASAN}

\section{Gambaran Kawasan Wisata Setu Rawalumbu}

\section{Kondisi Geografis}

Setu Rawalumbu merupakan salah satu setu dari ribuan setu yang ada di Indonesia. Berdasarkan data yang diperoleh dari Kementerian PUPR, jumlah setu di Indonesia pada tahun 2013 ada sebanyak 1,580 buah yang tersebar diberbagai propinsi (Gambar 4). Kepulauan Bangka dan Belitung merupakan propinsi yang paling banyak mempunyai setu, yaitu 546 buah. Sementara Kalimantan Utara, Papua Barat, Sulawesi Barat, dan Kepulauan Riau, merupakan propinsi-propinsi yang tidak mempunyai setu sama sekali. Propinsi DKI Jakarta sendiri mempunyai setu sebanyak 45 buah, sementara Propinsi Jawa Barat, mempunyai 127 setu, dimana salah satu diantaranya adalah Setu Rawalumbu yang berlokasi di Kota Bekasi. Meskipun setu mempunyai nilai ekonomis karena dapat dijadikan objek wisata (eco-tourism), namun masih banyak setu yang belum dimanfaatkan secara optimal. Bahkan banyak setu yang berubah fungsi menjadi daerah pemukiman, yang akibatnya dapat mengganggu keseimbangan ekosistem. Setiap setu harus dimanfaatkan dan dikembangkan sesuai dengan potensi sumber daya alamnya masing-masing dengan tetap mempertahankan keseimbangan ekosistem.

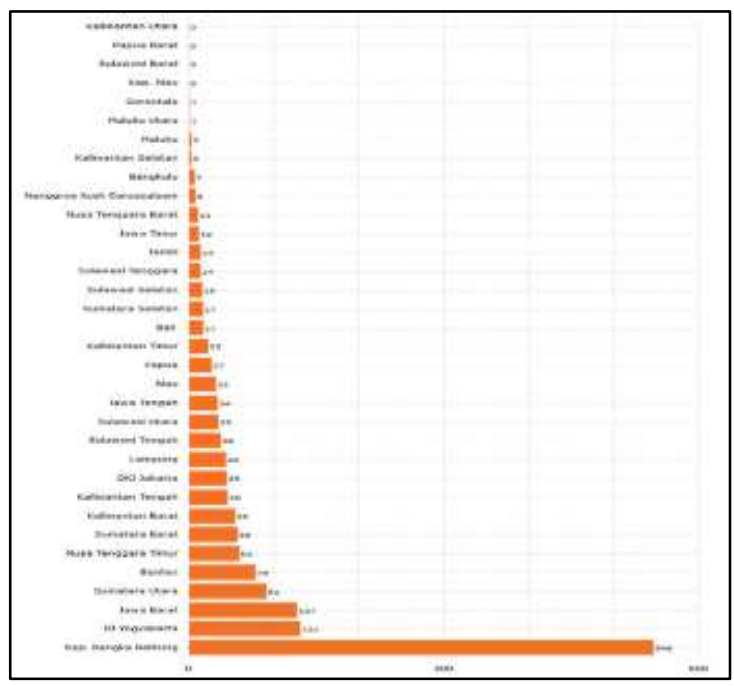

Gambar 4. Jumlah Setu Berdasarkan Propinsi di Indonesia Pada Tahun 2013 (Sumber: Kementerian PUPR, 2014)

Seperti yang telah dijelaskan diatas, Setu Rawalumbu merupakan setu yang terdapat di Kota Bekasi, Propinsi Jawa Barat. Kota Bekasi merupakan bagian dari wilayah metropolitan Jabodetabek yang dari waktu kewaktu mengalami perkembangan ekonomi dan jasa yang sangat pesat. Secara geografis, Kota Bekasi terletak di bagian utara Jawa Barat antara 106o48'28" - 107o27'29" Bujur Timur dan 6o30'6" Lintang Selatan (Gambar 5). 
Volume 2, Nomor 1, Tahun 2020 Hal 352 - 378

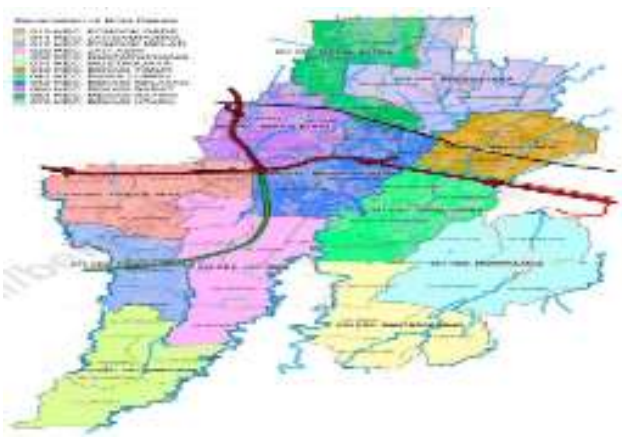

Gambar 5. Peta Kota Bekasi (Sumber: Badan Pusat Statistik Kota Bekasi, 2018)

Kondisi topografi Kota Bekasi relatif datar (kemiringan lahan bervariasi rata-rata 0-3\%) dan merupakan daerah beriklim panas dengan suhu $280 \mathrm{C}$ - 32oC, kelembaban antara $80 \%$ $90 \%$, yang dipengaruhi oleh angin musim barat dan musim timur. Kota Bekasi mempunyai 12 kecamatan dengan luas area 21.049,000 Ha, dimana salah satu kecamatan tersebut adalah kecamatan Rawalumbu, yang luasnya $8.01 \%$ dari luas Kota Bekasi (Tabel 3.1.). Dilihat dari jumlah penduduk, pada tahun 2017, Kota Bekasi mempunyai 2.409.083 penduduk dan 725.559 keluarga yang tersebar di seluruh kecamatan yang ada di Kota Bekasi. Kecamatan Rawalumbu sendiri mempunyai 224.641 penduduk, yaitu 9,32\% dari total jumlah penduduk Kota Bekasi dengan jumlah keluarga ada sebanyak 70.173 keluarga. Jumlah rata-rata anggota keluarga ada sebanyak 3 orang per keluarga.

Tabel 1. Luas Wilayah, Jumlah Penduduk, Jumlah Keluarga Menurut Kecamatan di Kota Bekasi Pada Tahun 2017 (Sumber: Badan Pusat Statistik Kota Bekasi, 2018)

\begin{tabular}{lrrr}
\hline Kecamatan & Luas $(\mathrm{Ha})$ & Penduduk & Keluarga \\
\hline Pondokgede & $1.591,562$ & 239.035 & 73.872 \\
Jatisempurna & $1.954,973$ & 116.987 & 36.855 \\
Pondok Melati & $1.179,925$ & 130.769 & 39.230 \\
Jatiasih & $2.427,411$ & 222.105 & 65.887 \\
Bantargebang & $1.843,890$ & 105.123 & 32.918 \\
Mustika Jaya & $2.641,557$ & 170.950 & 48.374 \\
Bekasi Timur & $1.463,410$ & 241.209 & 75.577 \\
Rawalumbu & $1.685,280$ & 224.641 & 70.173 \\
Bekasi Selatan & $1.606,120$ & 212.434 & 62.420 \\
Bekasi Barat & $1.492,680$ & 268.754 & 82.855 \\
Medansatria & $1.188,270$ & 158.526 & 47.012 \\
Bekasi Utara & $1.974,822$ & 318.550 & 90.386 \\
\hline Kota Bekasi & 21.049 .000 & 2.409 .083 & 725.559 \\
\hline
\end{tabular}

Kecamatan Rawalumbu dimana Setu Rawalumbu berada merupakan bagian dari Kota Bekasi yang terletak di wilayah selatan Kota Bekasi yang berperan juga sebagai penyangga lbu Kota Jakarta yang dalam perkembangannya telah menunjukan kemajuan diberbagai bidang sesuai dengan peran dan fungsinya. Kecamatan Rawalumbu terdiri dari 4 kelurahan yaitu Kelurahan Pengasinan (luas 272,47 Ha), Kelurahan Bojong Rawalumbu (luas 581,92 $\mathrm{Ha}$ ), Kelurahan Bojong Menteng (luas 370,187 Ha), dan Kelurahan Sepanjang Jaya (luas 295, 24 Ha) (Gambar 3.3.). Kecamatan Rawalumbu terdiri dari 98 RW dan 640 RT. Berdasarkan pembentukannya, batas Kecamatan 
Volume 2, Nomor 1, Tahun 2020 Hal 352 - 378

Rawalumbu adalah: sebelah barat berbatasan dengan Kecamatan Bekasi Selatan dan Kecamatan Jati Asih, sebelah selatan berbatasan dengan Kecamatan Bantar Gebang, sebelah utara berbatasan dengan Kecamatan Bekasi Timur dan Kecamatan Bekasi Selatan, dan sebelah Timur berbatasan dengan Kecamatan Mustika Jaya.

Setu Rawalumbu terdapat di Jalan Siliwangi RT 002 dan RW 041 Kelurahan Bojong Rawalumbu, Kecamatan Rawalumbu, Kota Bekasi yang berada pada koordinat 06011.979"Lintang Selatan dan 106031.385"Bujur Timur. Luas Setu Rawalumbu sekitar 23.675m2 (Gambar 3.4). Setu Rawalumbu berada di dua RW, yaitu RW 001 dan RW 041. RW 001 terdiri dari 10 RT

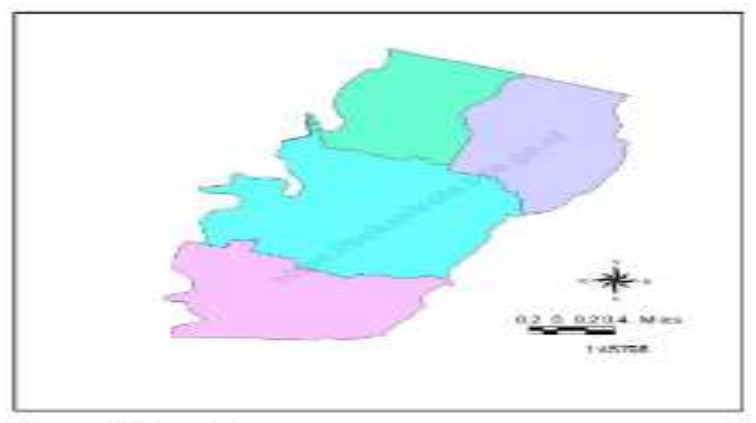

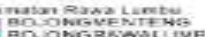

Gambar 6. Peta Kecamatan Rawalumbu Kota Bekasi, 2018)

(Sumber: Badan Pusat Statistik)

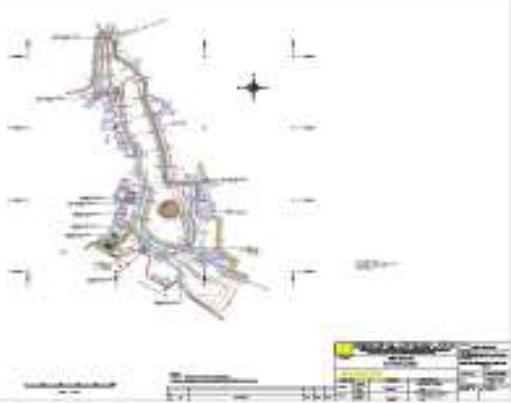

Gambar 7. Kawasan Setu Rawalumbu (Sumber: Kementerian PUPR, 2016) dan luasnya $4 \mathrm{Ha}$. Jumlah kepala keluarga di RW 001 ada sebanyak 1.343 Kepala Keluarga dengan jumlah penduduk 4.759 orang. Sedangkan RW 041 terdiri dari 10 RT dengan luas $3,5 \mathrm{Ha}$ yang dihuni oleh 945 kepala keluarga. Jumlah penduduk di RW 041 ada sebanyak 2.901 orang. Pemerintah Kota Bekasi, dengan mempergunakan dana APBD telah membangun Bank Sampah di daerah Setu Rawalumbu, dimana Bank Sampah ini dikelola oleh warga RW001 dan warga RW041. Jika dikelola dengan baik, Bank Sampah ini bisa menambah pendapatan bagi masyarakat sekitar. Meskipun tujuannya baik, pembangunan Bank Sampah itu bisa menyalahi aturan karena dibangun di daerah konservasi lingkungan.

Pada saat sekarang ini, di kawasan Setu Rawalumbu sudah muncul banyak permasalahan. Permasalahan yang muncul terjadi di sekitar ataupun pada Setu Rawalumbu, diataranya adalah sebagian daerahnya sudah beralih fungsi menjadi perkebunan (kebun pisang). Disamping itu, di sekitar Setu Rawalumbu sudah banyak terdapat rumah semi permanen, musholla, lapangan olah raga dan juga terdapat kolam pemancingan ikan. Selain itu, sebagian Setu Rawalumbu dipergunakan untuk tempat pembuangan sampah sementara (TPS) Warga Kelurahan Bojong Rawalumbu, dimana sampah-sampah tersebut berantakan dan meluber sampai menutup saluran dan membuat air bau. Lebih jauh lagi, sistem kelistrikan di kawasan tersebut juga tidak 
Volume 2, Nomor 1, Tahun 2020 Hal 352 - 378

menunjukkan kondisi yang aman, dimana sambungan dan tarikan kabel listrik dari tiang listrik ke rumah-rumah penduduk sangat semrawut (Gambar 8.). Jarak tiang listrik ke rumah penduduk sangat jauh sehingga kabel listrik yang menghubungkan dari tiang listrik ke rumah penduduk kendur dan bergelantungan
(Gambar 9), yang mana kondisi ini sangat membahayakan masyarakat di sekitar. Penyaluran energi listrik ke konsumen atau rumah-rumah tidak sesuai dengan persyaratan-persyaratan energy access yang telah ditetapkan pada Sustainable Development Goals (SDGs).

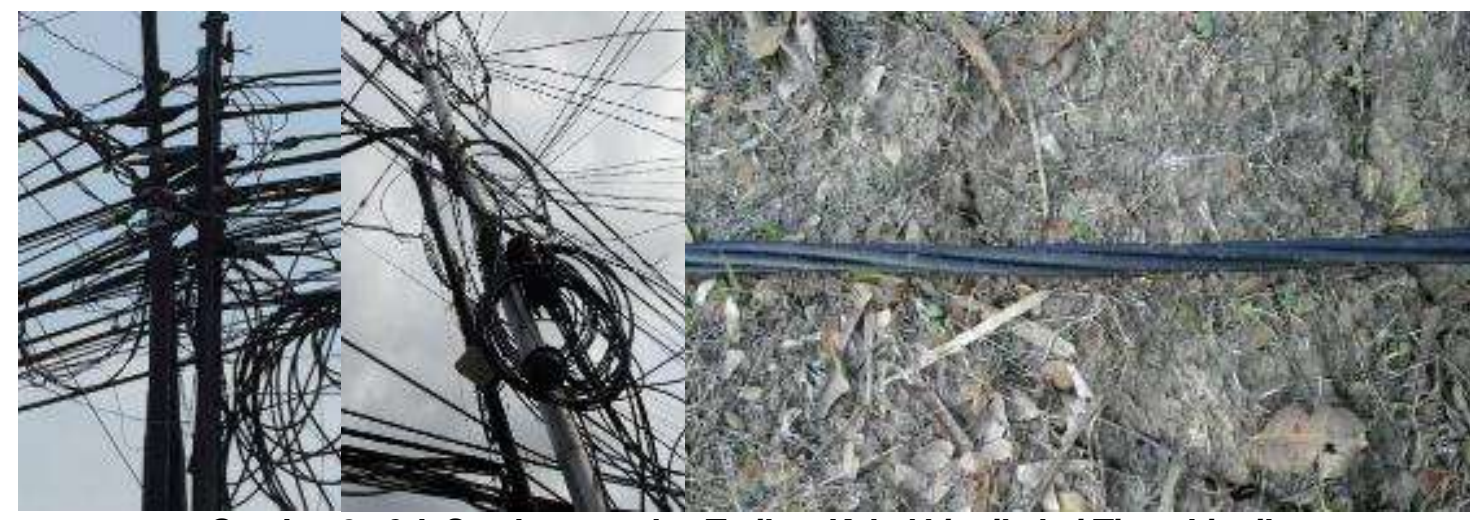

Gambar 8a \& b Sambungan dan Tarikan Kabel Listrik dari Tiang Listrik Gambar 9. Kabel Listrik yang Kendur dan Bergelantungan

matahari adalah parameter yang paling penting untuk menghasilkan energi listrik

Potensi Sumberdaya Matahari dan Solar PV

Kawasan Setu Rawalumbu merupakan bagian dari wilayah metropolitan Jabodetabek. Jadi data yang dipergunakan untuk membahas potesi sumberdaya matahari dan solar PV di Kawasan Wisata Setu Rawalumbu mempergunakan data Jakarta. Radiasi melalui solar PV, karena merupakan bahan bakar untuk pembangkit listrik tenaga surya. Potensi sumber daya matahari di Kawasan Wisata Setu Rawalumbu bila dibanding dengan kota-kota lain di Indonesia, Daerah Kawasan Wisata Rawalumbu termasuk daerah yang mempunyai Global Horizontal Irradiation (GHI), Global Tilted Irradition (GTI), dan Temperatur yang tinggi (Tabel 3.2). 
Volume 2, Nomor 1, Tahun 2020 Hal 352 - 378

Tabel 2. Jumlah Harian Rata-Rata dari Irraditiation (kWh/m2) dan Perbedaan Persentase GTI vs GHI (\%) Pada Kemiringan Optimal Modul PV 100 di Kawasan Wisata Setu Rawalumbu Kota Bekasi (Sumber: The World Bank 2017)

\begin{tabular}{lcccc}
\hline Bulan & $\begin{array}{c}\text { Global Horizontal } \\
\text { Irradiation (GHI) } \\
(\mathrm{kWh} / \mathrm{m} 2)\end{array}$ & $\begin{array}{c}\text { Global Tilted } \\
\text { Irradition (GTI) } \\
(\mathrm{kWh} / \mathrm{m} 2)\end{array}$ & $\begin{array}{c}\text { Direct Normal } \\
\text { Irradiation (DNI) } \\
(\mathrm{kWh} / \mathrm{m} 2)\end{array}$ & $\begin{array}{c}\text { GTI vs GHI } \\
(\%)\end{array}$ \\
\hline Januari & 3,94 & 3,77 & 1,92 & -4 \\
Febuari & 3,90 & 3,80 & 1,68 & -3 \\
Maret & 4,69 & 4,70 & 2,64 & 0 \\
April & 4,71 & 4,86 & 2,90 & 3 \\
Mei & 4,63 & 4,91 & 3,19 & 6 \\
Juni & 4,47 & 4,80 & 3,18 & 7 \\
Juli & 4,74 & 5,07 & 3,39 & 7 \\
Agustus & 5,28 & 5,52 & 3,55 & 5 \\
September & 5,60 & 5,68 & 3,48 & -2 \\
Oktober & 5,21 & 5,12 & 2,70 & -4 \\
November & 4,63 & 4,45 & 2,19 & -5 \\
Desember & 4,17 & 3,97 & 1,87 & 1 \\
\hline Tahun & 4,67 & 4,73 & 2,73 & \\
\hline
\end{tabular}

Meskipun ketiga parameter tersebut dapat saling melemahkan dalam memproduksi energi listrik melalui solar PV, misalnya tingginya temperatur dapat mempengaruhi efisiensi solar PV, Kawasan Wisata Setu Rawalumbu termasuk daerah yang mempunyai potensi menghasilkan energi listrik melalui solar PV yang tinggi. Ini menunjukkan di Kawasan Wisata Setu Rawalumbu dapat dibangun microgrid yang terhubung dengan solar PV berskala sedang dan besar. Agar produksi energi listrik di daerah ini optimum, maka pemasangan solar PV di daerah ini harus dipasang dengan kemiringan $10 \mathrm{o}$. Selain memproduksi energi listrik yang tinggi, manfaat dari pemasangan modul solar PV yang dimiringkan adalah untuk meningkatkan pembersihan sendiri terhadap polusi yang terdapat pada permukaan solar PV tersebut oleh hujan. Kotoran pada permukaan solar PV yang tinggi dapat menyebabkan kerugian yang besar. Tabel 3.2 menunjukkan GHI dan GTI bulanan dari Kawasan Wisata Setu Rawalumbu. Tabel 3.2 menunjukkan GHI terendah tercatat pada bulan Febuari yaitu 3,90 sementara $\mathrm{GHI}$ tertinggi berada pada bulan September yaitu 5,60. Untuk GTI posisi tertinggi berada pada bulan September, yaitu 5,68 sementara posisi terendah berada pada bulan Januari, yaitu 3,77. Rata-rata tahunan GHI dan GTI di Kawasan Wisata Setu Rawalumbu adalah masing-masing 4,67 dan 4,73 .

Disamping pilihan terhadap teknologi, posisi geografis juga sangat menentukan produksi energi listrik yang dihasilkan oleh sebuah solar PV. Kawasan Wisata Setu Rawalumbu sendiri berada pada posisi geografis yang dapat menghasilkan energi listrik melalui solar PV yang tinggi. Tabel 3.3. menunjukkan kinerja tahunan dari sebuah solar PV dengan modul tetap pada sudut optimum di Kawasan Wisata Setu Rawalumbu Kota Bekasi. 
Tabel 3. Kinerja Tahunan dari Parameter Sebuah Sistem Solar PV Dengan Modul Tetap Pada Sudut Optimum di Kawasan Wisata Setu Rawalumbu Kota Bekasi (The World Bank, 2017)

\begin{tabular}{lc}
\hline Parameter & Kinerja Tahunan \\
\hline Rata-Rata Total Harian PVOUT (kWh/kWp) & 3,58 \\
Total Tahunan PVOUT (kWh/kWp) & 1.309 \\
Sudut Optimum & 100 \\
Azimuth Sistem PV & 00 \\
Rasio Tahunan Difuse/Global Horizontal Irradiation & $57,2 \%$ \\
Rasio Kinerja (Performance Ratio atau PR) Sistem & $75,9 \%$ \\
\hline
\end{tabular}

Dari Tabel 3. dapat dilihat rata-rata total harian energi listrik yang dihasilkan oleh solar PV di daerah tersebut adalah 3,58 kWh/kWp atau dalam satu tahun sebuah sistem PV dengan modul tetap dapat menghasilkan $1.309 \quad \mathrm{kWh} / \mathrm{kWp}$. Sebagai bahan perbandingan, di Indonesia untuk kota-kota penghasil energi listrik yang tinggi melalui solar $\mathrm{PV}$, total harian rata-rata produksi energi listrik melalui sebuah solar PV yang mempunyai spesifikasi yang sama bervariasi antara 3.0 $\mathrm{kWh} / \mathrm{kWp}$ (sama dengan total rata-rata tahunan sekitar $1100 \quad \mathrm{kWh} / \mathrm{kWp}$ ) di pegunungan tinggi dan berawan, dan 4,6 kWh/kWp (sekitar 1680 kWh/kWp tahunan), yaitu nilai tertinggi di Indonesia, yang terdapat di pulau-pulau selatan kepulauan. Perlu dicatat bahwa daerah dengan potensi produksi listrik melalui solar PV tinggi adalah daerah dengan nilai Global Tilted Irradition (GTI) dan Direct Normal Irradiation (DNI) tinggi serta nilai Difuse (DIF) yang lebih rendah. Rasio DIF/GHI yang tinggi mengindikasikan banyak awan dan aerosol yang dapat menyebabkan produksi energi listrik rendah. Faktor lain yang dapat mempengaruhi produksi energi listrik melalui solar PV adalah kondisi iklim mikro (misalkan suhu udara), serta juga pohon, tiang-tiang, serta bangunan di sekitar solar PV dapat mempengaruhi penurunan kinerja sistem solar PV.

Kalau melihat rata-rata produksi listrik harian tiap bulan melalui sebuah sistem solar PV tetap yang berada di ruang terbuka (openspace fixed PV system) di Kawasan Wisata Setu Rawalumbu seperti yang diperlihatkan pada Tabel 3.4., bulan Januari merupakan bulan yang memproduksi energi listrik paling rendah, yaitu 2,85 $\mathrm{kWh} / \mathrm{kWp}$, sementara produksi listrik yang dihasilkan paling tinggi berada pada bulan September, yaitu 4,27 kWh/kWp. Sementara Rasio Kinerja (Performance Ratio) tertinggi berada pada bulanan Juni dan Juli, yaitu $76,3 \%$, sedangkan yang terendah berada pada bulan September, yaitu $75,2 \%$. 
Tabel 4. Jumlah Harian Rata-Rata Produksi Listrik dan Rasio Kinerja Bulanan Dari Sebuah Sistem Solar PV Tetap yang Berada di Ruang Terbuka (OpenSpace Fixed PV System) Dengan Daya Puncak Normal 1 kW di Kawasan Wisata Setu Rawalumbu Kota Bekasi (kWh/kWp) (Sumber: TheWorld

Bank, 2017)

\begin{tabular}{lcc}
\hline Bulan & $\begin{array}{c}\text { Jumlah Harian Rata-Rata } \\
\text { Produksi Listrik } \\
(\mathrm{kWh} / \mathrm{kWp})\end{array}$ & $\begin{array}{c}\text { Rasio Kinerja } \\
\text { Bulanan } \\
(\%)\end{array}$ \\
\hline Januari & 2,85 & 75,7 \\
Febuari & 2,89 & 76,0 \\
Maret & 3,57 & 76,0 \\
April & 3,69 & 75,9 \\
Mei & 3,74 & 76,1 \\
Juni & 3,66 & 76,3 \\
Juli & 3,87 & 76,3 \\
Agustus & 4,19 & 75,8 \\
September & 4,27 & 75,2 \\
Oktober & 3,86 & 75,4 \\
November & 3,37 & 75,8 \\
Desember & 3,02 & 76,1 \\
\hline Tahun & 3,58 & 75,9 \\
\hline
\end{tabular}

Jika dilihat pada skala nasional, jika dilakukan analisis SWOT (Strength, Weaknesess, Opportunities, Threats) terhadap potensi pemanfaatan sumber daya matahari untuk memproduksi energi listrik dari solar PV di Indonesia, maka dapat dijelaskan masingmasing kekuatan, kelemahan, peluang, dan ancaman sebagai berikut (The World Bank, 2017):

a. Kekuatan (Strengths)

i. Sumber daya matahari dan potensi tenaga solar PV yang bagus

ii. Teknologi sudah ada dan matang untuk off-grid dan sistem mini-grid/microgrid untuk komunitas terpencil

iii. Tersedia program untuk instalasi solar PV dari Pemerintah

b. Kelemahan (Weaknesses) i. Pulau atau daerah dengan komunitas kecil dan terisolasi

ii. Batasan medan, antara lain: medan dengan ketinggian tinggi, kemiringan yang curam, daerah terlindungi dari sinar matahari, dan aksesibilitas terbatas

iii. Tingginya biaya koneksi ke jalur tegangan tinggi (main grid) untuk daerah-daerah terpencil

iv. Polusi udara di daerah perkotaan besar yang dapat mengotori permukaan panel solar PV

c. Peluang (Opportunities)

i. Meningkatnya permintaan listrik

ii. Program dukungan internasional

iii. Sikap positif terhadap energi terbarukan

iv. Biaya solar PV yang terus menurun 
Volume 2, Nomor 1, Tahun 2020 Hal 352 - 378

v. Solar PV dapat dikombinasikan dengan sumber energi terbarukan lainnya (terutama hidro) untuk membantu menangani variabilitas sumber matahari

vi. Potensi solar PV untuk bersinergi dengan pembangkit listrik berbahan bakar gas

d. Ancaman (Threats)

i. Risiko geografis dan kejadian ekstrem, seperti: erupsi gunung berapi, gempa bumi, tanah longsor, tsunami, dll.

ii. Sumber daya matahari yang sangat bervariasi

iii. Letusan gunung berapi

\section{Energy Access}

Energy access adalah target (goal) ke 7 dari Sustainable Development Goals (SDGs) yang berbunyi "energy access to affordable, reliable, sustainable, and modern energy for all'. Akses energi (energy access) didefinisikan sebagai kemampuan untuk memperoleh energi yang memadai, tersedia saat dibutuhkan, andal, berkualitas baik, terjangkau, legal, nyaman, sehat, dan aman untuk semua kebutuhan energi yang diperlukan di seluruh rumah tangga, perusahaan, dan lembaga masyarakat. Akses listrik yang rendah telah menjadi metafora untuk kemiskinan dan keterbelakangan di sebagian besar negara berkembang. Konsumsi listrik per kapita yang memiliki korelasi langsung dengan indeks pembangunan telah digunakan sebagai ukuran kesejahteraan ekonomi suatu masyarakat.
Energi modern (modern energy) biasanya mengacu pada sumber energi yang bersih, aman, dan, sampai batas tertentu, nyaman. Energi listrik adalah sumber energi yang nyaman dan sering dianggap sebagai sumber yang bersih, setidaknya pada titik penggunaan. Akses terhadap energi listrik aman jika pemasangan kabel yang terhubung ke rumah tangga (atau fasilitas lain) dilakukan sesuai dengan standar nasional, untuk memastikan bahwa orang-orang dilindungi dari bahaya yang mungkin timbul dari pemanfaatan energi listrik. Keamanan biasanya diukur melalui terjadinya kecelakaan di masa lalu (Bhatia dan Angelou 2014). Berkenaan dengan akses energi ke solusi memasak bersih (clean cooking solution), energi modern didefinisikan melalui memasak eksposur dan efisiensi kompor (Padam et al. 2018; Dave et al. 2018; Koo et al. 2018). Memasak eksposur dihitung dari ketahanan seseorang terhadap polutan yang dihasilkan dari kegiatan memasak, yang tergantung pada emisi kompor, ventilasi, dan waktu kontak. Yang dimaksud dengan efisiensi kompor adalah kinerja kompor sehubungan dengan efisiensi termal. Kenyamanan juga dipertimbangkan, diukur melalui waktu yang dihabiskan untuk memperoleh bahan bakar, serta menyiapkan bahan bakar dan kompor untuk memasak.

Energi telah lama diakui sebagai hal yang esensial bagi manusia untuk berkembang, tetapi berdasarkan Sustainable Development Goals (SDGs), energi juga dirasakan penting untuk pembangunan. Akses 
Volume 2, Nomor 1, Tahun 2020 Hal 352 - 378

terhadap energi listrik sangat penting untuk pencapaian tujuan-tujuan (goals) lainnya yand ada di SDGs. Menyediakan koneksi ke rumah tangga tidak cukup untuk memastikan pembangunan ekonomi dan sosial berhasil. Listrik harus tersedia dengan andal dan terjangkau, tidak hanya bagi rumah tangga untuk mengakses layanan yang bermanfaat tetapi juga untuk kegiatan yang menghasilkan pendapatan dan layanan publik. Peningkatan kualitas teknologi desentralisasi (distributed power generator) serta menurunnya biaya dari pembangkit tersebut menawarkan peluang baru untuk memberikan akses energi listrik yang universal, meskipun masih banyak tantangan, terutama dalam menyediakan akses energi listrik yang terjangkau bagi rumah tangga miskin dan lokasinya terpencil.

Sampai sejauh ini, dampak dari target (goal) ke 7 dari SDGs sangat significant. Jumlah orang tanpa akses energi listrik turun di bawah angka 1,1 miliar untuk pertama kalinya pada tahun 2016. Hampir 1,2 miliar orang telah mendapatkan akses energi listrik sejak tahun 2000. Jaringan listrik telah menjadi sumber terhadap akses energi listrik dan diperkirakan 97\% orang telah memperoleh koneksi sejak tahun 2000 (IEA, 2017). IEA memperkirakan bahwa untuk memberikan akses listrik yang universal pada tahun 2030, solusi desentralisasi adalah opsi yang paling murah bagi $60 \%$ orang yang tidak memiliki akses listrik. Perluasan jaringan diharapkan meningkat dengan meningkatnya permintaan daya dan kegiatan ekonomi. Saat ini, solusi akses listrik dengan memanfaatkan sistem terdesentralisasi masih kecil, tetapi akan semakin cepat bertumbuh. IEA memperkirakan bahwa 33 juta orang akan memiliki akses ke energi listrik yang dibangkitkan melalui energi terbarukan yang terdesentralisasi, dengan tingkat koneksi yang semakin cepat. IRENA memperkirakan bahwa secara global, kapasitas listrik terbarukan yang berasal dari sistem off-grid untuk keperluan perumahan dan komersial adalah sekitar 4.030 MW (IRENA, 2017). Sistem kelistrikan yang terdesentralisasi juga dapat memberikan manfaat bagi penciptaan lapangan kerja lokal dan pertumbuhan ekonomi.

Peranan microgrid saat ini sangat terbatas, dan diperkirakan akan meningkat di masa mendatang, terutama ketika inisiatif akses energi listrik bertujuan untuk menyediakan listrik untuk kegiatan komersial dan peningkatan produktifitas, serta aktifitas rumah tangga. Untuk pengembangan dan operasi microgrid yang berkelanjutan, diperlukan suatu lingkungan yang kondusif melalui kebijakan dan peraturan khusus, mekanisme pembiayaan yang disesuaikan untuk kepentingan pengembangan dan operasi microgrid, kerangka kerja kelembagaan yang profesional, fokus pada pengembangan kapasitas, dan adaptasi terhadap teknologi. Agar lingkungan lebih kondusif, maka diperlukan kebijakan dan peraturan yang sesuai untuk pengembangan dan operasi microgrid yang mencakup: strategi elektrifikasi pedesaan yang jelas, kerangka kerja perizinan yang disesuaikan, mekanisme penanganan kompensasi integrasi microgrid ke jaringan 
Volume 2, Nomor 1, Tahun 2020 Hal 352 - 378

utama (main grid), aturan yang jelas untuk menetapkan tarif dalam mendorong investasi dan memungkinkan operasi yang berkelanjutan, dan langkah-langkah untuk memfasilitasi akses ke jasa keuangan (misalnya bank) untuk pengembang dan pengguna akhir (IEA, 2017; IRENA, 2016).

Meningkatkan akses ke pasokan energi modern dan andal serta harga terjangkau secara luas dianggap sebagai prasyarat untuk pembangunan ekonomi di negara-negara berkembang dan negaranegara dengan ekonomi dalam transisi. Microgrid dapat digunakan untuk meningkatkan akses listrik di daerah yang tidak terjangkau oleh jaringan transmisi dan distribusi listrik nasional.

\section{Microgrid}

Konsep microgrid pertama kali
2002 (Lasseter, 2004). Microgrid adalah pola pembangkit terdistribusi yang mencakup berbagai sumber energi, mulai dari teknologi bahan bakar fosil yang bersih dan efisien (seperti turbin mikro) yang dikombinasikan dengan combined heat power (CHP), serta teknologi energi terbarukan yang ramah lingkungan seperti solar PV, fuel cell, energy storage, biogas, angin, hidro. Komponenkomponen dari microgrid tersebut dapat dilihat pada Gambar 3.6. Kombinasi berbagai sistem pembangkit energi yang saling melengkapi berdasarkan energi terbarukan atau campuran (energi terbarukan dengan cadangan biofuel/diesel generator) dikenal sebagai sistem hibrid energi terbarukan. Grid yang dibentuk oleh sistem ini dikenal sebagai microgrid karena ukurannya lebih kecil dibandingkan dengan grid utama.

dikembangkan oleh $\mathrm{R}$. H. Lasseter pada tahun

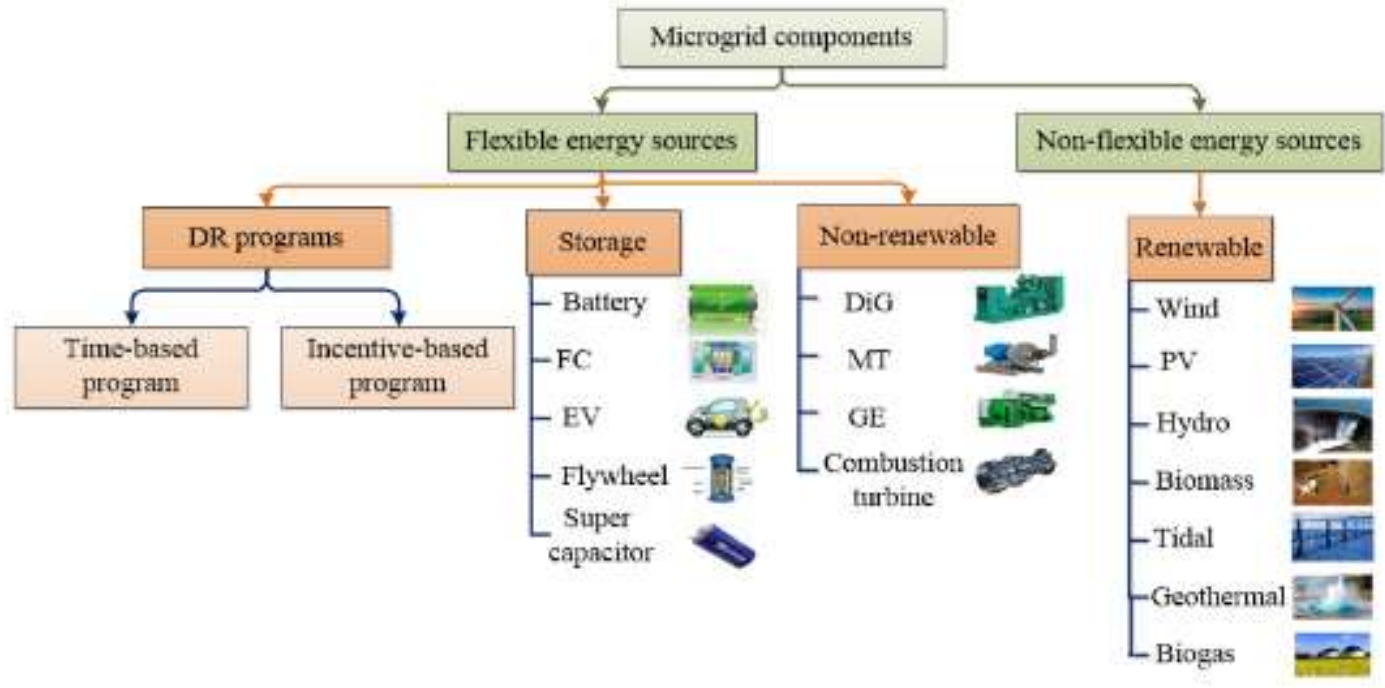

\section{Gambar 10. Komponen-Komponen Microgrid}

Teknologi energi terbarukan menghasilkan banyak manfaat, baik terhadap lingkungan maupun ekonomi. Menurut definisi, teknologi energi terbarukan tidak menggunakan bahan bakar fosil, yang berarti mereka menghasilkan emisi gas rumah kaca yang rendah atau nol 
Volume 2, Nomor 1, Tahun 2020 Hal 352 - 378

dan polusi yang lebih sedikit. Investasi dalam teknologi terbarukan membawa manfaat tambahan dalam merangsang lapangan kerja dan pertumbuhan ekonomi, yang menggerakkan dunia lebih dekat ke ekonomi rendah karbon (IEl, 2015; Singh, 2017). Mengingat kesenjangan yang semakin besar antara pasokan dan permintaan energi, energi terbarukan telah mengambil peran penting dalam memenuhi meningkatnya permintaan energi, terutama oleh industri di negara-negara berkembang. Beberapa teknologi energi terbarukan telah muncul sebagai pilihan yang layak secara ekonomi dan ramah lingkungan, yang jika diadopsi dengan tepat, dapat memenuhi pertumbuhan kebutuhan energi industri, khususnya usaha kecil dan menengah
(UKM). Jika merancang sistem hibrida untuk produksi energi listrik, berbagai aspek harus dipertimbangkan, seperti biaya dan dampak lingkungan (emisi CO2). Disamping itu, ketersediaan (availability) dan keandalan (reliability) akan menjadi salah satu masalah utama juga (Vera, 2019). Jaringan listrik microgrid adalah sistem jaringan interkoneksi dari berbagai sumber energi yang didistribusikan ke jaringan kecil yang dapat beroperasi secara independen atau terhubung ke jaringan utama atau nasional untuk memungkinkannya beroperasi dalam mode jaringan-terhubung (grid-connected) atau mode-pulau (island-mode). (Gambar 11).

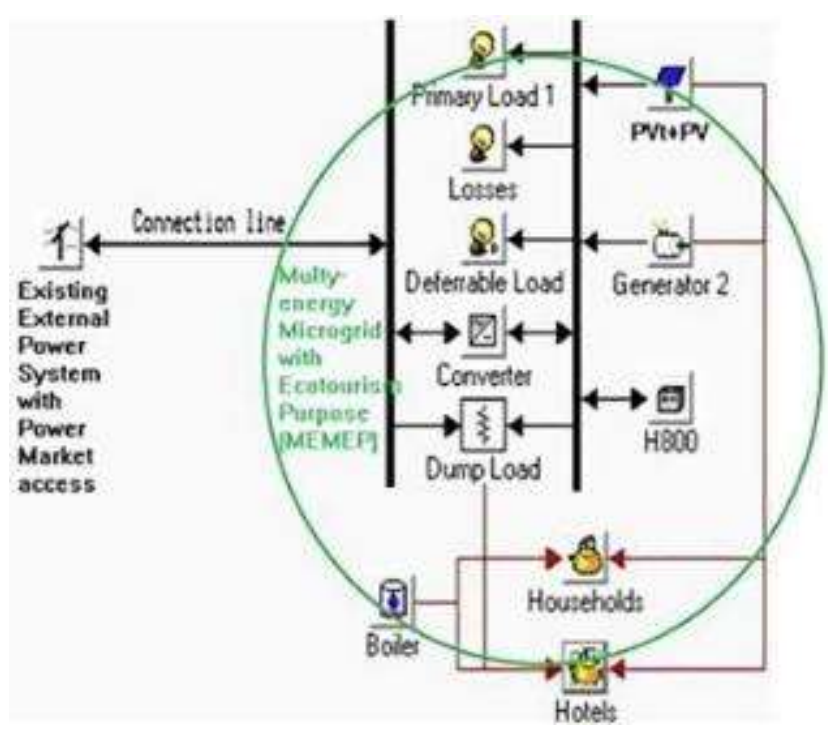

\section{Gambar 11. MEMEP (Multy-Energy Microgrid with Ecotourism Purpose) Microgrid} yang Terhubung ke Jaringan Utama (Sumber: Homer Pro, 2018)

Tujuan dari pengembangan microgrid di Kawasan Wisata Setu Rawalumbu adalah untuk menawarkan sambungan listrik yang aman, terjangkau dan andal guna meningkatkan kualitas hidup dan membuka peluang untuk meningkatkan pendapatan lokal. Suplai listrik bertujuan agar masyarakat dapat memacu pertumbuhan ekonomi, menarik investasi untuk bisnis dan menyediakan lapangan kerja di Kawasan Wisata Setu Rawalumbu yang saat ini kurang berkembang. Pada prinsipnya, microgrid 
Volume 2, Nomor 1, Tahun 2020 Hal 352 - 378

menawarkan tiga manfaat dalam tiga bidang yang berbeda, yaitu (a) keamanan dan keandalan energi, (b) penghematan bahan bakar, (c) manfaat lingkungan, yaitu mengurangi emisi. Ketiga manfaat ini akan dijelaskan melalui Gambar 12 dibawah ini.

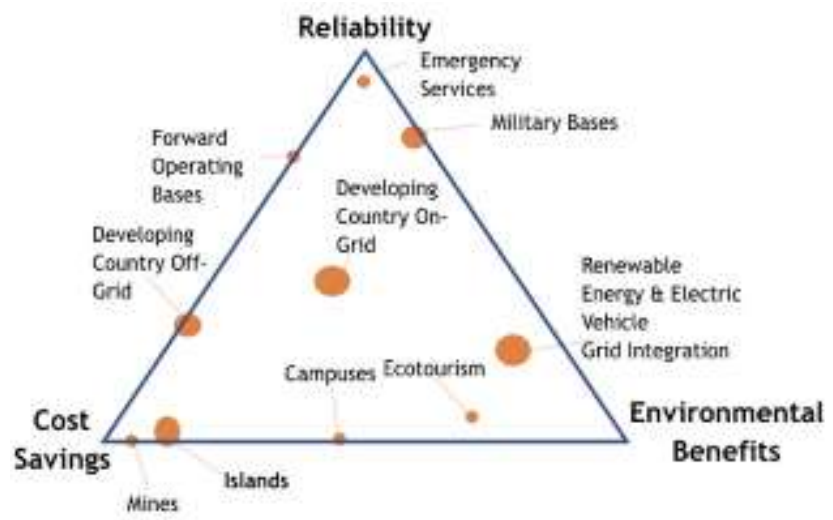

Gambar 12. Nilai Manfaat dari Microgrid (Sumber: Homer Pro, 2018)

\section{a. Microgrid untuk keandalan}

Kelebihan dari sistem microgrid adalah dilihat dari keandalannya. Dilihat dari sisi keandalan, sistem microgrid mempunyai keandalan yang sangat tinggi, bahkan lebih tinggi dari pensuplai energi listrik lokal. Seringkali pengguna akhir energi listrik memerlukan layanan yang berkelanjutan bahkan pada saat kondisi ekstrem, seperti badai, gempa bumi, atau mungkin selama situasi pemadaman listrik "rutin" di jaringan listrik (misalnya karena terjadi gangguan di sistem jaringan distribusi) yang menyebabkan gangguan dalam penyaluran listrik ke beban pelanggan. Dalam kondisi ekstrim, mempertahan aliran listrik ke beban agar tetap mengalir menjadi hal yang sangat penting. Bahkan dalam kondisi seperti ini, biaya menjadi sesuatu yang sekunder yang artinya berapapun biaya akan dikeluarkan, yang penting aliran listrik tetap berjalan. Jalan satu-satunya untuk mengatasi pemadaman ini adalah dengan menempatkan pembangkit dan penyimpanan listrik (energy storage) dekat di lokasi pengguna akhir atau konsumen, atau di sisi beban. Konsumen yang membutuhkan keandalan yang tinggi, selalu memiliki sistem cadangan lokal. Sistem cadangan lokal yang biasanya dipergunakan adalah sistem daya tak terputus atau Uninterupptible Power Supply (UPS) berbasis baterai untuk beban kecil dan generator bolak-balik yang berbahan bakar diesel, propana, atau gas alam untuk beban yang lebih besar. Microgrid adalah suatu sistem yang mengintegrasikan teknologi-teknologi ini dengan switchgear otomatis, manajemen beban (load management), dan sistem tenaga yang mempergunakan energi terbarukan. Sistem microgrid ini menghasilkan energi listrik yang lebih bersih dan lebih efisien yang dapat beroperasi untuk waktu yang lama tanpa adanya pengiriman bahan bakar yang cukup berarti. Keandalan yang tinggi ini biasanya dibutuhkan oleh pusat data, rumah sakit, laboratorium, pangkalan militer, dll.

b. Microgrid untuk penghematan bahan bakar 
Volume 2, Nomor 1, Tahun 2020 Hal 352 - 378

Meskipun sebagian besar sistem energi

Sistem microgrid mempunyai berbagai memiliki skala ekonomis yang besar dimana sistem yang lebih besar akan lebih efisien dibanding dengan sistem yang lebih kecil, namun ada tiga faktor yang merupakan keuntungan ekonomi dari microgrid dalam aplikasi tertentu, yaitu (i) tidak diperlukannya transportasi pipa untuk menyalurkan gas alam dari sumbernya ke pembangkit listrik dan juga transportasi batubara yang membawa batubara dari penambangan ke pembangkit tenaga lisrik. Sebagai gantinya microgrid mempergunakan diesel dan bahan bakar minyak (biofuel) untuk pembangkit listrik, yang membuat sistem tenaga hibrida yang terbarukan pada microgrid sangat kompetitif, (ii) panel surya (solar PV) adalah sumber daya terbarukan yang tumbuh paling cepat dan harganya terus menurun, dimana jika diaplikasikan pada skala kecil ataupun besar biayanya hampir sama, (iii) sistem combined heat and power (CHP) dapat menjadi sangat hemat biaya jika mempergunakan panas yang dibangkitkan di tempat, terlebih lagi jika memanfaatkan panas limbahnya.

c. Microgrid untuk manfaat lingkungan

Microgrid yang menggunakan energi terbarukan tujuannya adalah untuk mengurangi konsumsi diesel dan juga mengurangi dampak lingkungan. Lebih penting lagi, microgrid dapat memanfaatkan manajemen beban (load management) dan penyimpanan energi (energy storage) yang dibangkitkan pembangkit listrik terdistribusi untuk mengelola variabilitas penetrasi tinggi tenaga surya dan angin. macam segmen pasar untuk diterapkan, diantaranya dapat dijelaskan sebagai berikut:

a. Layanan darurat

Layanan darurat seperti rumah sakit, kantor polisi, pusat data, fasilitas telekomunikasi selalu memiliki sistem daya cadangan. Untuk keperluan sistem daya cadangan ini, pemasangan generator diesel sederhana sudah memadai, kecuali pemadaman sangat sering terjadi sehingga pengoperasian dan pemeliharaan generator diesel menjadi masalah, meskipun kasus ini umumnya terjadi di negara-negara berkembang, bukan negara maju. Kalau kasusnya seperti ini, maka microgrid energi terbarukan menjadi menarik. Layanan microgrid energi terbarukan ini akan menghapus kebutuhan akan pengiriman bahan bakar selama keadaan darurat yang bisa sampai berkepanjangan.

b. Pangkalan Militer Permanen (Permanent Military Bases)

Pangkalan Militer Permanen adalah pangkalan yang dipersiapkan fasilitas layanan darurat yang tujuannya agar mereka dapat beroperasi secara mandiri dalam waktu yang lama. Oleh karena itu, microgrid energi terbarukan sangat sesuai dipasang di pangkalan tersebut.

c. Pangkalan Operasi Depan (Forward Operating Bases atau FOB)

Pangkalan Operasi Depan atau Titik Kontrol Masuk (Entry Control Point atau ECP) adalah pangkalan militer yang berada di posisi terdepan yang digunakan untuk mendukung tujuan strategis dan tujuan taktis. FOB dapat 
Volume 2, Nomor 1, Tahun 2020 Hal 352 - 378

berisi lapangan terbang, rumah sakit, machine shop, atau fasilitas logistik lainnya. Berhubung karena di dalam FOB banyak objek vital, maka sangat penting dibangun microgrid di dalam FOB. Penggunaan microgrid untuk akses terhadap energi listrik didalam FOB akan costeffective dibanding generator diesel karena pengiriman bahan bakar untuk keperluan generator diesel tersebut menjadi tantangan logistik yang sangat serius yang dapat membatasi kemampuan tentara untuk memenuhi misi mereka dan juga membahayakan keselamatan tentara yang mengangkut bahan bakar.

d. Fasilitas Komersial dan Rumah Tangga Berpenghasilan Tinggi di Negara Berkembang

Sebagian besar jaringan listrik di negara berkembang tidak cukup andal untuk memenuhi kebutuhan fasilitas komersial dan rumah tangga menengah ke atas. Untuk keperluan tersebut, jutaan generator kecil yang menghasilkan polusi dioperasikan setiap hari di seluruh negara berkembang. Jika generator ini beroperasi cukup sering, maka pemakaian microgrid energi terbarukan akan lebih menghemat karena terjadinya pengurangan bahan bakar dan biaya perawatan.

e. Mensuplai Energi Listrik ke Desa-Desa di Negara-Negara Berkembang

Lebih dari satu setengah miliar orang tidak memiliki akses terhadap energi listrik, dan orang-orang ini biasanya tinggal di pedesaan. Desa-desa ini terlalu terpencil atau terlalu kecil untuk dilayani oleh jaringan listrik konvensional. Pada awalnya, HOMER itu dibuat untuk melayani daerah-daerah seperti ini. Umumnya beban listrik yang letaknya terpencil seperti ini dilayani oleh solar home system (SHS) dalam beberapa jam saja, selebihnya dilayani dengan generator diesel. Jika mempergunakan microgrid energi terbarukan, daerah ini dapat mengakses energi selama 24 jam. Sebenarnya daerah pedesaan bukan pasar yang layak secara komersial pada saat ini untuk memasarkan microgrid karena kurangnya infrastruktur pendukung di bidang energi terbarukan, tetapi faktor kemiskinan energi menjadi daya tarik bagi banyak lembaga pembangunan dan filantropi untuk memasang microgrid energi terbarukan. Di daerah pedesaan, microgrid dapat memberi pelayanan sebagaimana seperti apa yang dilakukan oleh sebuah perusahaan listrik besar. Kalau dilihat keadaan saat sekarang ini, sebagian besar microgrid yang beroperasi di seluruh dunia saat ini melayani beban listrik di daerah yang tidak memiliki jaringan listrik (mis. pulau-pulau terpencil kecil, komunitas terpencil, dll.).

\section{f. Kepulauan}

Negara kepulauan (negara yang mempunyai banyak pulau) merupakan daerah yang sangat baik dipasang microgid energi terbarukan. Pulau-pulau di negara kepulauan umumnya tidak terjangkau jaringan listrik utama, dan sebagai gantinya mereka menggunakan generator diesel untuk membangkitkan energi listrik. Biaya membangkitkan energi listrik dengan cara seperti ini sangat tinggi, yaitu antara \$ 0,40 - \$2,00 per kWh dibanding dengan rata-rata $\$ 0,11$ per $\mathrm{kWh}$ di daerah 
Volume 2, Nomor 1, Tahun 2020 Hal 352 - 378

yang terjangkau oleh jaringan listrik utama. Untuk mengatasinya, pemasangan sistem mikrogrid energi terbarukan akan lebih menguntungkan.

g. Tambang

Industri pertambangan memiliki banyak lokasi terpencil yang sumber listriknya berasal pembangkit diesel skala besar. Listrik tersebut lebih banyak dipergunakan untuk keperluan teknis. Untuk kondisi seperti ini, microgrid sangat bermanfaat di daerah pertambangan.

h. Kampus

Pada saat sekarang ini, banyak kampus suatu universitas ataupun perguruan tinggi yang mempunyai banyak bangunan yang peruntukannya berbeda-beda, misalnya untuk ruang perkuliahan, laboratorium, perkantoran, fasilitas olah raga, perumahan karyawan dan dosen, rumah sakit, kantin, asrama mahasiswa mulai memasang microgrid. Microgrid dapat menjadi menarik secara ekonomi (cost-attractive) jika mereka dapat memanfaatkan combined heat power (CHP) atau jika ada insentif yang menarik dari pemerintah untuk pemasangan energi terbarukan (berbagai jenis insentif untuk pemasangan energi terbarukan dapat dilihat pada sub-bab 3.6).

\section{i. Ekowisata}

Resort ekowisata merupakan pasar kecil tapi ideal untuk pemasaran microgrid energi terbarukan. Banyak resort ekowisata yang terletak di daerah terpencil dan tanpa adanya akses ke jaringan listrik (main grid). Dilihat dari keinginan tamu, pemasangan generator diesel tidak akan cocok untuk memperbaiki citra pemasaran, karena berbagai sebab, misalnya polusi, suara brisik, dan lain-lain. Oleh karena itu pemasangan microgrid energi terbarukan akan lebih sesuai untuk mengatasinya.

j. Integrasi Dengan Main Grid (Jaringan Utama)

Sistem microgrid yang terdiri dari energy storage, manajemen beban listrik (load management), dan distributed power generator (DPG) dapat mengatasi perubahan energi listrik yang dihasilkan pembangkit listrik tenaga matahari (solar PV) dan pembangkit listrik tenaga angin (wind turbine) yang cukup tinggi. Tingginya tingkat energi listrik yang dihasilkan oleh solar PV dan wind turbine menyebabkan grid mengalami kesulitan menyerap energi listrik yang dihasilkan oleh pembangkit listrik energi terbarukan tersebut. Tapi dengan adanya microgrid yang dilengkapi dengan energy storage dan kemampuan load management, energi listrik yang dihasilkan oleh solar PV dan wind turbine akan mampu untuk dikendalikan untuk dikirim ke main grid (jaringan utama) dengan stabil. Inilah sebenarnya manfaat microgrid yang paling penting, disamping manfaat biaya (costeffective) dan keandalan.

k. Integrasi Dengan Kendaraan Listrik Kendaraan listrik adalah penggerak pasar masa depan yang dapat bersinergi dengan microgrid. Kendaraan hibrida plug-in electric vehicles adalah kombinasi penyimpanan terdistribusi dan pembangkitan (distributed storage and generation) yang dapat berfungsi baik sebagai sistem tenaga cadangan dan sumber energi terbarukan. Kenderaan listrik 
Volume 2, Nomor 1, Tahun 2020 Hal 352 - 378

dapat diintegrasikan dengan sistem microgrid untuk menyalurkan energi yang terdapat pada microgrid ke kenderaan listrik, atau sebaliknya.

\section{Homer Pro®}

Perancangan sistem microgrid untuk Kawasan Wisata Setu Rawalumbu menggunakan perangkat lunak microgrid The HOMER Pro® yang dipergunakan untuk menganalisis kinerja teknis dan ekonomi dari sistem microgrid. Perangkat lunak microgrid HOMER Pro® yang dikembangkan oleh HOMER Energy adalah alat yang dipergunakan sebagai standar global untuk mengoptimalkan desain microgrid di semua sektor, mulai dari listrik desa dan utilitas pulau hingga kampus dan pangkalan militer yang terhubung ke jaringan. Awalnya The HOMER Pro® dikembangkan di National Renewable Energy Laboratory (NREL), dan kemudian ditingkatkan dan didistribusikan oleh HOMER Energy, HOMER (Hybrid Optimization Model for Multiple Energy Resources) merupakan perangkat lunak yang mampu melakukan analisa teknik dan analisa ekonomi secara bersamaan. Pada intinya, HOMER adalah model simulasi yang mencoba untuk mensimulasikan sistem yang layak untuk semua kemungkinan kombinasi peralatan yang ingin dipertimbangkan. Bergantung pada bagaimana kita memformulasi suatu permasalahan, HOMER dapat mensimulasikan ratusan atau bahkan ribuan sistem. HOMER mensimulasikan pengoperasian microgrid hibrida selama satu tahun penuh, dalam langkah waktu dari satu menit hingga satu jam. HOMER memeriksa semua kemungkinan kombinasi jenis sistem dalam sekali proses, dan kemudian mengurutkan sistem sesuai dengan variabel optimasi pilihan. HOMER Pro® menghadirkan algoritma pengoptimalan yang secara signifikan menyederhanakan proses desain untuk mengidentifikasi opsi paling murah untuk microgrid atau sistem tenaga listrik generasi terdistribusi lainnya. HOMER Optimizer ${ }^{\mathrm{TM}}$ adalah algoritma optimasi eksklusif yang dirancang khusus untuk bekerja di HOMER. HOMER memungkinkan kita mengajukan sebanyak mungkin pertanyaan "bagaimana jika?", karena kita tidak dapat mengontrol semua aspek sistem, dan kita tidak dapat mengetahui pentingnya variabel atau opsi tertentu tanpa menjalankan ratusan atau ribuan simulasi dan membandingkan hasilnya. HOMER memudahkan untuk membandingkan ribuan kemungkinan dalam sekali jalan. Ini memungkinkan kita untuk melihat dampak variabel yang berada di luar kendali kita, seperti kecepatan angin, biaya bahan bakar, dll, dan memahami bagaimana sistem optimal berubah dengan variasi-variasi ini. HOMER Pro® dapat disesuaikan hingga 9 modul individual untuk memenuhi kebutuhan pemodelan spesifik kita, yaitu: Biomass, Hydro, Combined Heat Power (CHP), Advanced Load, Advanced Grid, Hidrogen, Advanced Sorage, Multi-Year, Link MATLAB Link (Homer Energy, 2019).

\section{Data Komponen Untuk Perancangan Sistem Microgrid}


Volume 2, Nomor 1, Tahun 2020 Hal 352 - 378

Komponen-komponen yang digunakan untuk merancang sistem microgrid untuk Kawasan Wisata Setu Rawalumbu adalah solar PV, Generator, Inverter dan Energy Storage (Penyimpanan Energi) dalam bentuk Baterai, dan ATS (Automatic Transfer Switch). Adapun data-data masing-masing komponen dapat dijelaskan sebagai berikut:

a. Solar PV

Jenis solar PV yang dipergunakan adalah jenis solar PV flat plate photovoltaic LONGi Solar LR6-60 BP dengan kapasitas 0,305 kW, efisiensi $18,7 \%$ dan luas modul (H/W/D) 1650x991 x40 mm, life time 25 tahun (Sumber: Solaris Technology Industry, Alibaba dan Zerohomebills)

- Biaya modal (initial capital cost) = $\$ 187,16 /$ piece

- Harga $=\$ 0,25-0,35 /$ watt

b. Generator

Jenis generator yang dipergunakan adalah generator diesel jenis HP 6700 LN dengan kapasitas 2 kW (Sumber: Indotara.co.id dan Bukalapak.com serta inkuiri.com)

- Biaya modal (initial capital cost) = $\$ 468,26 / 2 k W$

- Biaya operasi dan pemeliharaan = \$0,030/.op.jam

- Harga bahan bakar diesel $=\$ 0,393 / 1$

- Fuel comsumption =0,374 l/kWh

- Harga Solar dari Badan Pengatur Hilir Minyak dan Gas Bumi (BPH MIGAS) (http://www.bphmigas.go.id/harga-bbmspbu/)

c. Converter
Jenis converter yang dipergunakan adalah jenis PRETTL REFU sol $08 \mathrm{~K}$ dengan kapasitas $2 \mathrm{~kW}$ dan efisiensi inverter $97.30 \%$ life time 25 tahun

- Biaya modal (initial capital cost) = $\$ 501,01 / \mathrm{kW}$

- Harga $=\$ 0,501 /$ Watt

d. Energy Storage Jenis energy storage yang dipergunakan adalah jenis Trojan SSIG 12 255, 12 V, nominal capacity 3,09 kWh, kapasitas maksimum 257 Ah (Sumber: Trojan Battery Company, renvu.com dan Battery Heaven \& Solar Solution, phtotovoltaicshop.com):

- Biaya modal (initial capital cost) $=\$$ 360,.14/piece

- Biaya penggantian (Replacement cost $)=\$$ 360,14

- Biaya operasi dan pemeliharaan $=\$ 10,00$

e. Automatic Transfer Switch

Jenis Automatic Transfer Switch yang dipergunakanlah adalah dengan spesifikasi sebagai berikut:

- Kapasitas Inverter 2000Watt (MSW)

- Smart Charger 4 step Inteligent (10A)

- Unit Control ATS (Automatic Transfer Switch)

- Panel Box 30×40×25 (cm)

- Input PLN 180-240V/50Hz

- Dual Output Mode

- Harga $=\$ 178,56$

Kebijakan Pemasangan Energi Terbarukan

Pemerintah pada saat ini mendorong investasi dan penggunaan energi terbarukan. Pada saat sekarang ini, banyak program dan 
Volume 2, Nomor 1, Tahun 2020 Hal 352 - 378

insentif yang dapat dipelajari dari beberapa negara maju yang telah melakukan program insentif tersebut, dan diharapkan Pemerintah Indonesia dapat belajar dari negara-negara maju tersebut bagaimana mereka meningkatkan penggunaan energi terbarukan. Salah satu sumbernya yang dapat dijadikan sumber informasi yang komprehensif adalah "Database of State Incentives for Renewables \& Efficiency (DSIRE)". Beberapa contoh diantaranya adalah insentif pajak atau kredit yang dipergunakan untuk mengkualifikasi teknologi dan proyek energi terbarukan misalnya Renewable Electricity Production Tax Credit (PTC), the Investment Tax Credit (ITC), the Residential Energy Credit (REC), dan the Modified Accelerated Cost-Recovery System (MACRS). Selain itu, adanya program hibah dan pinjaman yang tersedia di beberapa lembaga pemerintah di beberapa negara. Ada juga insentif finansial yang tersedia untuk mendukung atau mensubsidi pemasangan peralatan energi terbarukan, misalnya:

\section{a. Renewable Portfolio Standard (RPS)}

RPS mengisyaratkan agar persentase penjualan tenaga listrik yang berasal dari sumber energi terbarukan besarnya sesuai target yang telah ditetapkan. Beberapa negara telah membuat target-target ini, tetapi ada juga negara yang telah membuatnya dengan sukarela. Kepatuhan terhadap kebijakan RPS terkadang akan mengharuskan atau mengizinkan perdagangan Renewable Energy Certificates.

b. Renewable Energy Certificates or Credits (RECs)
RECs adalah produk keuangan yang tersedia untuk dijual, dibeli, atau diperdagangkan yang memungkinkan pembeli membayar untuk produksi energi terbarukan tanpa secara langsung mendapatkan energi dari sumber energi terbarukan. RECs dapat digunakan oleh perusahaan listrik untuk memenuhi RPS yang telah ditetapkan oleh negara. Ada juga green tags atau green certificates, yang dipergunakan untuk memfasilitasi pembelian produksi energi terbarukan oleh konsumen di area di mana perusahaan listrik lokal tidak menawarkan green power option.

\section{c. Net Metering}

Net Metering memungkinkan pelanggan perusahaan listrik untuk memasang sistem energi terbarukan yang telah memenuhi persyaratan di rumah atau property mereka dan menghubungkan sistem yang mereka punyai ke sistem distribusi perusahaan listrik (atau jaringan listrik). Programnya bervariasi, tetapi secara umum, perusahaan listrik menagih net metering pelanggan mereka untuk jumlah bersih listrik yang digunakan pelanggan selama periode yang ditentukan. Jumlah bersihnya adalah total konsumsi listrik pelanggan dikurangi jumlah listrik yang dihasilkan oleh sistem energi terbarukan pelanggan. Di beberapa negara, pelanggan perusahaan listrik dapat menjual kelebihan listrik yang mereka hasilkan ke perusahaan listrik. Untuk maksud tersebut, perusahaan listrik telah mengembangkan net metering khusus agar dapat mengatasi masalah tersebut. Sebagian besar yang mempergunakan sistem net metering adalah 
Volume 2, Nomor 1, Tahun 2020 Hal 352 - 378

mereka yang memasang sistem energi terbarukan yang berasal dari solar PV.

d. Feed-in Tariff (FIT)

FiT adalah tarif yang ditetapkan khusus oleh perusahaan listrik untuk membeli listrik dari beberapa jenis sistem yang membangkitkan energi listriknya dari energi terbarukan. Tujuan dari FiT adalah untuk mendorong proyek baru dari jenis teknologi energi terbarukan yang spesifik. Tarif FiT ini umumnya lebih tinggi dari tarif listrik yang diterapkan pada generator yang tidak mempergunakan energi terbarukan.

e. Green Power Purchasing

Pada saat sekarang ini banyak konsumen di hampir setiap negara dapat membeli green power (energi hijau), yaitu listrik yang dihasilkan dari jenis sumber daya energi terbarukan yang spesifik. Pembelian green power ini dapat dilakukan oleh pelanggan ataupun perusahaan listrik melalui sebuah kontrak yang telah ditetapkan.

\section{f. Etanol dan bahan bakar motor terbarukan} lainnya

Ini adalah insentif yang berlaku untuk produksi, penjualan, dan penggunaan etanol, biodiesel, dan bahan bakar lain yang terbuat dari biomassa. Misalnya mewajibkan menggunakan 36 miliar galon biofuel di Amerika Serikat pada tahun 2022. Jenis biofuel yang dijual bisa dalam bentuk yang lain dari yang disebutkan diatas, asalkan terbuat dari biomasa.

\section{KESIMPULAN DAN SARAN}

\section{Kesimpulan}

Untuk meningkatkan akses terhadap energi listrik di Kawasan Wisata Setu Rawalumbu Kota Bekasi, maka pemasangan microgrid energi terbarukan merupakan salah satu opsi yang dapat dilakukan untuk keperluan ekowisata dan aktifitas masyarakat di daerah tersebut. Energi terbarukan yang dapat dipasang sesuai dengan keadaan alam di Kawasan Wisata Setu Rawalumbu adalah solar PV. Dalam sistem microgrid, biasanya dipergunakan kombinasi beberapa pembangkit atau sistem hibrid, dimana solar PV tersebut di back-up oleh generator diesel (micro turbine) berbahan bakar bioethanol agar listrik yang dihasilkan oleh generator tersebut masih dalam kategori clean energi (energi bersih) atau green energi (energi hijau). Tidak tertutup kemungkinan jika pada microgrid dipasang pembangkit listrik berbahan bakar biomas atau biogas atau jenis energi terbarukan lainnya jika bahan bakar tersebut memang tersedia di sekitar Kawasan Wisata Setu Rawalumbu. Rencana tata ruang dari Kawasan Wisata Setu Rawalumbu perlu dilakukan baik untuk jangka pendek, menengah maupun panjang agar dapat diketahui profil beban listrik di daerah tersebut sehingga model yang optimal dari sistem microgrid dapat ditentukan.

Dengan memasang sistem microgrid energi terbarukan juga berarti Kawasan Wisata Setu Rawalumbu membantu Pemerintah dalam mengurangi emisi gas rumah kaca serta mencapai bauran energi terbarukan, yaitu sebesar $23 \%$ pada tahun 2015 dan sebesar 31\% pada tahun 2050. 
Volume 2, Nomor 1, Tahun 2020 Hal 352 - 378

Disamping itu pihak pengelola microgrid bisa mendapatkan keuntungan lain berupa insentif dari Pemerintah akibat pemasangan sistem microgrid energi terbarukan.

\section{Saran}

Sistem microgrid energi terbarukan sebaiknya dipasang di Kawasan Wisata Setu Rawalumbu untuk meningkatkan akses terhadap energi listrik (clean energy atau green energy) baik untuk keperluan aktifitas ekowisata di Kawasan Wisata Setu Rawalumbu maupun untuk kebutuhan masyarakat sekitar.

\section{UCAPAN TERIMA KASIH}

Pelaksanaan Pengabdian Pada Masyarakat ini dilaksanakan berkaitan dengan Program Pengendalian dan Revitalisasi Sungai, Danau dan Rawa dari Komando Daerah Militer Jaya, bekerjasama dengan BBSCC (Balai Besar Sungai CiliwungCisadane). Kesempatan yang baik ini telah dimanfaatkan dengan baik oleh Programstudi Magister Arsitektur PPs UKI untuk yang kedua kali, setelah yang pertama dilaksanakan pada Situ Pengarengan dan Situ Gadog. Permasalahan yang ditemui di ketiga lokasi Situ tersebut sangat berbeda, tetapi pada umumnya tetap masalah pendangkalan dan limbah rumah tangga yang mengotori Situ.

Kesempatan mempelajari dan turut membantu perancangan wilayah ini, terutama masalah Energi Terbarukannya, dilakukan bersama mahasiswa Pascasarjana, di mana hal ini akan memberi wawasan lebih luas kepada mereka.
Terima kasih sebesar-besarnya kami sampaikan di sini kepada Kodam Jaya, Bapak Kolonel Jaky beserta jajarannya, pihak PU melalui BBSCC dan juga pada Universitas Kristen Indonesia yang telah memberi kemungkinan terjadinya kerjasama ini dan pembiayaan untuk pelaksanaannya. Semoga Kegiatan serupa di kemudian hari dapat kami laksanakan sebaik mungkin dan lebih banyak membantu masyarakat sekitar Situ dan Pemerintah Daerah terkait.

\section{DAFT AR PUSTAKA}

Angelou, N., Bhatia, M. (2014), Capturing the Multi-dimensionality of Energy Access" (English). Live wire knowledge note series; no. 2014/16. Washington, DC: World Bank Group. Dave, R., Keller, S., Koo, B., Fleurantin, G., Portale, E., Rysankova, D. (2018), Cambodia - Beyond Connections: Energy Access Diagnostic Report Based on the Multi-tier Framework (English). Washington, D.C.: World Bank Group.

BMKG (2019), Data Online - Pusat Database BMKG, http://dataonline. bmkg.go.id/home BPS (2018), Kecamatan Rawalumbu Dalam Angka 2018, Biro Pusat Statistik Kota Bekasi BPS (2018), Kota Bekasi Dalam Angka, Biro Pusat Statistik KotaBekasi

BPH Migas (2019), BBM Satu Harga, https://www.bphmigas.go.id/ bbmsatu-harga/

Cader, C., Bleachinger, P., Bertheau, P. (2016), Electrification planning with 
Volume 2, Nomor 1, Tahun 2020 Hal 352 - 378

focus on hybrid mini grids - A comprehensive modelling approach for the Global South, Energy Procedia Vo. 99, pp. 269-276.

El-Shimy, M.. (2017), Economics of Variable Renewable Sources for Electric Power Production., Saarbrücken: Lambert Academic Publishing.

He, L., Zhang, S., Chen, Y., Ren L., Li, J. (2018), Techno-economic potential of renewable energy-based microgrid system for a sustainable large-scale residential community in Beijing, China, Renewable and Sustainable Energy Reviews, Vol. 93, pp. 631641.

Homer Energy (2019), Homer Pro, https://www.homerenergy.com/ products/pro/index.html

IEA (International Energy Agency) (2017), Energy Access Outlook: World Energy Outlook Special Report, OECD/IEA, Paris.

IEA, UNDP, IRENA (2018), High Level Political Forum on Sustainable Development, Policy Brief\# 1, Achieving Universal Access to Electricity,

IRENA (2017), Renewable Energy Statistics, Abu Dhabi.

IRENA (2016), Policies and regulations for private sector renewable energy minigrids, Abu Dhabi

IEI (2015), Analyzing the Costs and Benefits of Community Microgrids, IEI, USA.
Kanagawa, M., Nakata, T. (2008), Assessment of access to electricity and the socio-economic impacts in rural areas of developing countries, Energy Policy, Vol. 36, pp. 2016-2019 Kemenristekdikti 92017),"Rencana Umum Energi Nasional (RUEN), Peraturan Presiden Nomor 22 Tahun 2017"

Kementerian PUPR (2017), Buku Informasi Statistik 2017, Kementerian Pekerjaan Umum dan Perumahan Rakyat.

Kementerian ESDM (2016), Statistik EBTKE 2016, Kementerian Energi dan Sumber Daya Mineral

Kementerian PUPR (2015), Permen PUPR No. 9 Tahun 2015 Tentang Penggunaan Sumber Daya Air, Kementerian Pekerjaan Umum dan Perumahan Rakyat.

Kementerian PUPR (2015), Permen PUPR No. 28 Tahun 2015 Tentang Garis Sempadan Sungai dan Garis Sempadan Danau pada pasal 23, Kementerian Pekerjaan Umum dan Perumahan Rakyat.

Koo, B., Rysankova, D., Portale, E., Angelou, N., Keller, S., Padam, G. (2018), Rwanda-Beyond Connections: Energy Access Diagnostic Report Based on the Multi-tier Framework (English). Washington, D.C.: World Bank Group.

Lasseter, R. H. (2004), Microgrid: a conceptual solution, IEEE Annual 
Volume 2, Nomor 1, Tahun 2020 Hal 352 - 378

Power Electronics Specialists

Conference 6:4285 - 4290 Vol.6.

Manalu, S., Marpaung, C.O.P. (2019),

Techno-Economic Analysis of a

Microgrid System To Increase

Electricity Access in Rural Areas, International Journal of Smart Grid and Sustainable Energy

Technologies.

Padam, G., Rysankova, D., Portale, E., Koo,

B., Keller, S., Fleurantin, G. (2018),

Ethiopia-Beyond Connections:

Energy Access Diagnostic Report

Based on the Multi-tier Framework

(English). Washington, D.C.: World

Bank Group.

Planas, E., Andreu, J., Garate, J. I., de Alegria, I. M., Ibarra, E. (2015), AC and $\mathrm{DC}$ technology in microgrids: $\mathrm{A}$ review, Renewable and Sustainable Energy Reviews, Vol. 43, pp. 726749.
Prinsloo, E. C. (2015), Impact of Renewable Energy Structures on Tourism, Research Report, University of Stellenbosch.

Singh, P. K. (2017), Technical and Economic Potential of Microgrids in California, Master Thesis, Hamboltd State University.

The Word Bank (2017), Solar Resource and Photovoltaic Potential of Indonesia, The World Bank, Washington DC.

Vera, Y. E. G., Lopez, R. D., Agustin, D. L. L. (2019), Energy management in microgrids with renewable energy sources: a literature review, Appl. Sci., Vol. 9, pp. 3854.

Ya, A. Z. (2016), Comparative Analysis of Innovative PV Microgrids in Paris and Nice, France, European Journal of Sustainable Development, Vol. 5, No. 3, pp. 297-310.

\section{LAMPIRAN 1: Solar Panel, Micro Turbine, Converter, Battery Energy Storage System, Automatic} Transfer Switch yang Dipasang Pada Sistem Microgrid

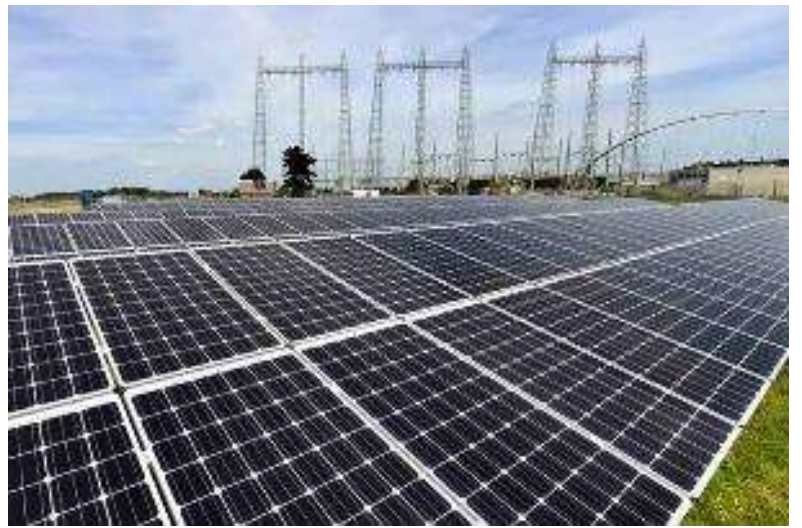

Solar Panel

\section{What is a Micro Turbine?}

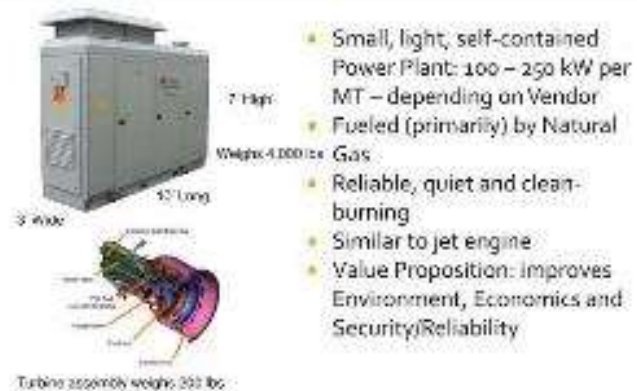

Micro Turbine 
Volume 2, Nomor 1, Tahun 2020 Hal 352 - 378
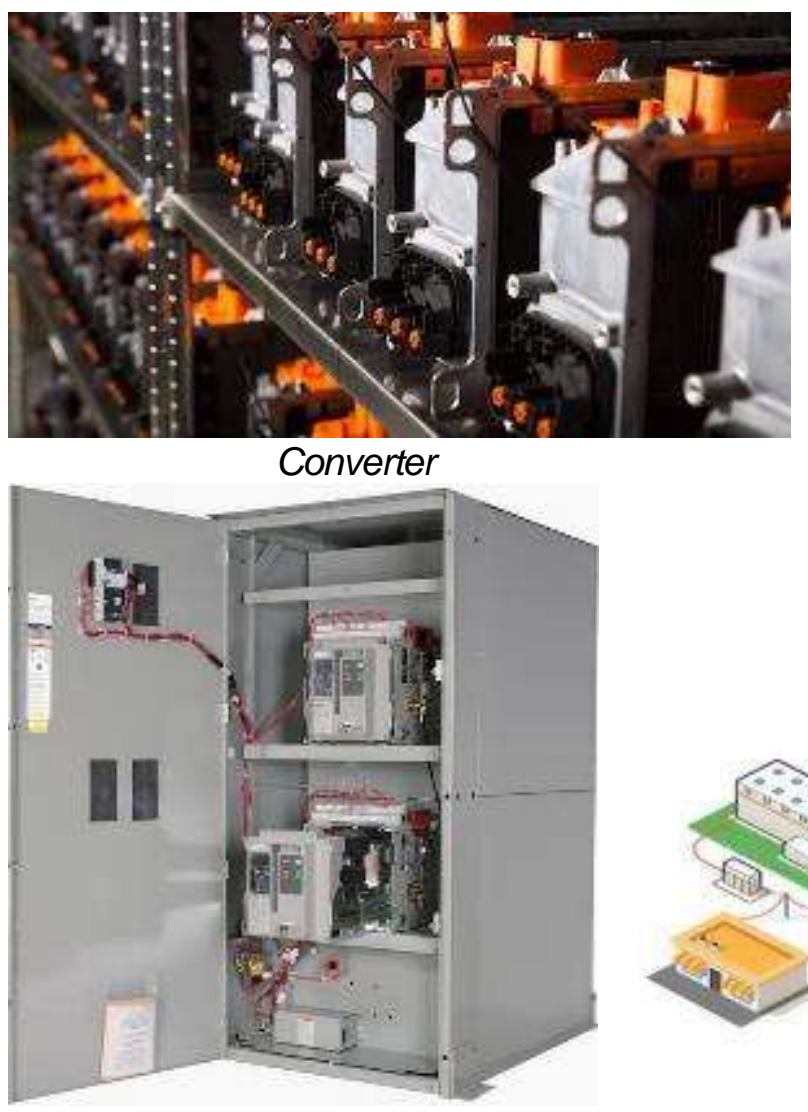

Automatic Transfer Switch (ATS)

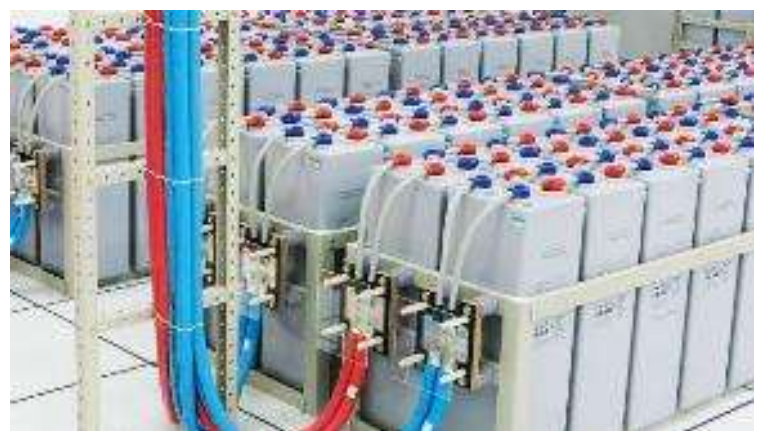

Battery Energy Storage System (BESS)

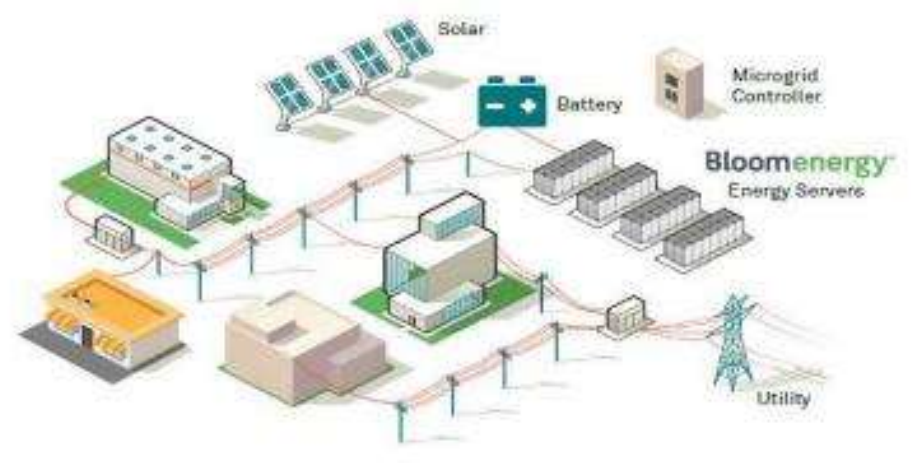

Sistem Microgrid 